\title{
Remittances from International Labour Migrants and the Standard of Living of the Left Behind Households in Sri Lanka
}

\author{
D. Siriwardhane ${ }^{a}$ \\ University of Sri Jayewardenepura, Sri Lanka \\ S.Amaratunge ${ }^{b}$ \\ University of Sri Jayewardenepura, Sri Lanka \\ I. De Silva ${ }^{c}$ \\ University of Colombo, Sri Lanka
}

\begin{abstract}
This study aims to examine the effect of remittances on the standard of living of the remittance receiving households in Sri Lanka. Survey data were analyzed using thematic analysis and stratified matching method in propensity score matching. It was found that, a large majority of labour migrants remit money to their households left behind. However, the volume of remittances varies with the demographic and socio-economic characteristics of the labour migrants and their households. Furthermore, it was found that remittance receiving households enjoy income from diversified sources. Average treatment effects estimated through stratified matching analysis reveal that remittance receivers enjoy a higher level of income and higher standard of living compared to their non-remittance receiving counterparts. Improvement of the income by the remittances varies with the income quintile of the households.
\end{abstract}

a. Ms. D. Siriwardhane is a Senior Lecturer at the Department of Business Economics, University of Sri Jayewardenepura, Nugegoda, Sri Lanka. E-mail: d.siriwardhane@sjp.ac.lk

b. Prof. S. Amaratunge is a Professor in Business Economics at the Department of Business Economics, University of Sri Jayewardenepura, Nugegoda, Sri Lanka.

c. Prof. I. De Silva is a Senior Professor, Demography (Chair) of the Faculty of Arts, University of Colombo, Sri Lanka. 


\section{Keywords}

Migration, Propensity Score Matching, Remittances, Sri Lanka

\section{Introduction}

International labour migration has become an attractive source of employment that brings a significant amount of foreign resources to Sri Lanka. During past four decades, migration for foreign employment, especially to Gulf Arab has grown rapidly. Remittances on the other hand have become the second largest flow of foreign resources flowing to the country.

Increasing labour migration, remittances and growing social concern in the Sri Lankan context has created an unfilled knowledge gap to be answered through a proper empirical examination. Recent discussions on migration have become a growing debate. Part of this debate is centered on social impacts of labour migration such as child development and family stability. Large representation of the females in the labour migration flow has intensified this argument in recent decades. The other part of the debate is centered on the emergent interest of the policy makers and researchers on the roles of remittances at the household and national levels.

In this backdrop, this article aims to answer the research question of 'how significant is the remittance income in the income profile and the standard of living of the remittance receiving households in Sri Lanka?' Objectives of the study are to elucidate the significance of remittances in the income profile of the households and examine the impact of remittances on the income and standard of living of the remittance receiving households. Findings of the study, is greatly important to understand the significance of international remittances at the household level. Hence the study is in a position to enrich the remittance literature in the Sri Lankan context. Further, this study is one of the few social science studies, employed stratified matching method in the propensity score analysis.

The rest of the paper consists with five sections. First section presents the literature review while the second section presents the recent trends of labour migration and remittances in Sri Lanka. Third section presents the 
data, variables and methods employed in the study. Fourth section presents the discussion of the results, while the fifth section derives the conclusions.

\section{Literature Review}

Labour migration in literature is rich in theories, models and empirical studies. Though the classical and neoclassical theories feed the migration literature they lack on the examination of the role of remittances. Addressing this literature gap, the theory of New Economics of Labour Migration (NELM) provides the foundation for remittance studies. While the conventional theories of labour migration view migration as an individual decision, theory of NELM views it as a collective decision taken at the household level. Migrant and the household have an implicit contractual arrangement, in which the household finances the migrant to migrate expecting future financial benefits (Stark \& Bloom, 1985). Hence, utility of the migrants is derived from the utility of the households. Maximization of the satisfaction of the household implies that maximization of the satisfaction of the labour migrant.

Migrants from low income earning countries earn a significantly larger income at host countries compared to their potential income at the home country (Clemens, Montenegro \& Pritchett, 2008). They remit part of the income to the households left behind as part of the contractual arrangement. Remittances help these households to diversify their income to survive in a financial shock (Chen, Chiang \& Leung, 2003; Taylor \& Rozelle, 2003). Arunatilake et al. (2010) and Munas (2008) have found that remittances increase the number of income sources of the households in Sri Lanka and support them to face the income shocks.

On the other hand, like other transfers, remittances enhance money income of the households. Hence remittance receivers enjoy a considerably high income compared to their non-remittance receiving counterparts (Cuong, 2008; Koc \& Onan, 2001; Castaldo \& Reilly, 2007). This provides the poor households a path to escape from poverty (Adams, 1991) and the opportunity to cover their important spending such as housing (Castaldo \& Reilly, 2007). Contribution of remittances to the household income lends a hand the remittance receiving households in Sri Lanka, to move up in the income ladder (De \& Ratha, 2012; Arunatilake et al., 2010). 
Remittances are type of transfers. However, remittances and other transfers have both similar and different characteristics. Unlike other transfers, remittances are earned money transferred to the households by labour migrants. It is the return that the households receive for sending labour abroad (Taylor \& Rozelle, 2003). Hence, remittances are the benefit that the households receive for the foregone household income through lost labour income (Brown \& Leeves, 2007). On the other hand, as other transfers remittances reduce the total labour supply (Ariola, 2008) and labour force participation of the household members (Bussolo \& Medvedev, 2007). Hence, it is important to consider the net effect of remittances in examining the benefit of labour migration and remittances (Brown \& Leeves, 2007; Wouterse \& Taylor, 2007).

While the literature has evaluated remittances as a source of household income, there is a lack of studies on the net effect of remittances at the household level. Studies like, Bouoiyour and Miftah (2014) and Randazzo and Piracha (2014) use propensity score matching method to examine the net effects of labour migration and remittances using matching techniques such as, nearest neighbor, Kernal and Gaussian matching.

However, in many of labour sending developing countries income inequality is rather high and the amount of remittance send by the migrants greatly varies with the migrant and household level characteristics. Hence, examining the net effect of remittances on income and income related variables; stratified matching method is more suitable. It is comparatively effective than other matching methods that reduces the selection bias significantly (Rosenbaum \& Rubin, 1984).

This study aims to fill the knowledge gap by elucidating the significance of remittances in the income profile of the households and examining the impact of remittances on the household income and standard of living of the remittance receiving households in the Sri Lankan context, employing stratified matching method in propensity score analysis. 


\section{International Labour Migration and Remittances in Sri Lanka: Recent Trends}

Sri Lanka has been a labour sending country for more than five decades. Migration of professionals to Europe and North America as long-term permanent migrants has started in 1960s (Gunatillake \& Colombage, 2010). However, labour migration to Gulf Arab was started growing remarkably in 1976 with the sharp increase in world oil price. Sudden growth in oil price made the Middle East countries financially strong and opened avenues for male unskilled workers and female domestic workers. However, skill and gender composition in the labour migration flow has been changing during past decades with the absorption of skilled labour migrants by Middle East and elsewhere. Figure 1 presents key indicators of labour migration and remittances in the Sri Lankan context.

At present, more than 300,000 people migrate abroad for work, per annum. About half of them are females. Even though the migration flow was predominantly represented by female workers for decades, it has been changing gradually. By the end of 1990s, female representation was as high as 75 percent of the total labour migrants. It has swiftly declined in the past two decades and reached to 37 percent in 2014. More than 80 percent of these female labour migrants are domestic workers, migrating to Arab countries. Skilled worker group, which is highly represented by males, is increasing gradually and becoming the largest group of labour migrants. Further, recent changes show slow increase in high skilled workers in professional and middle levels.

With the introduction of the open economic policies in 1978, the foreign employment industry in Sri Lanka has been accounted as the second largest earner of foreign exchange (Central Bank, 2013). At present, the worker remittance flow is over US\$7,000 million per annum (Central Bank, 2015). Almost 60 percent of the remittances flow from the Middle East. During past four decades, remittances have been increasing rapidly and become the most stable source of foreign resources. This remarkable increase in the remittances brings the idea into light that, Sri Lanka receives a significant amount of remittances as an important labour sending country. 

Figure 1: Labour Migration and Remittances in Sri Lanka

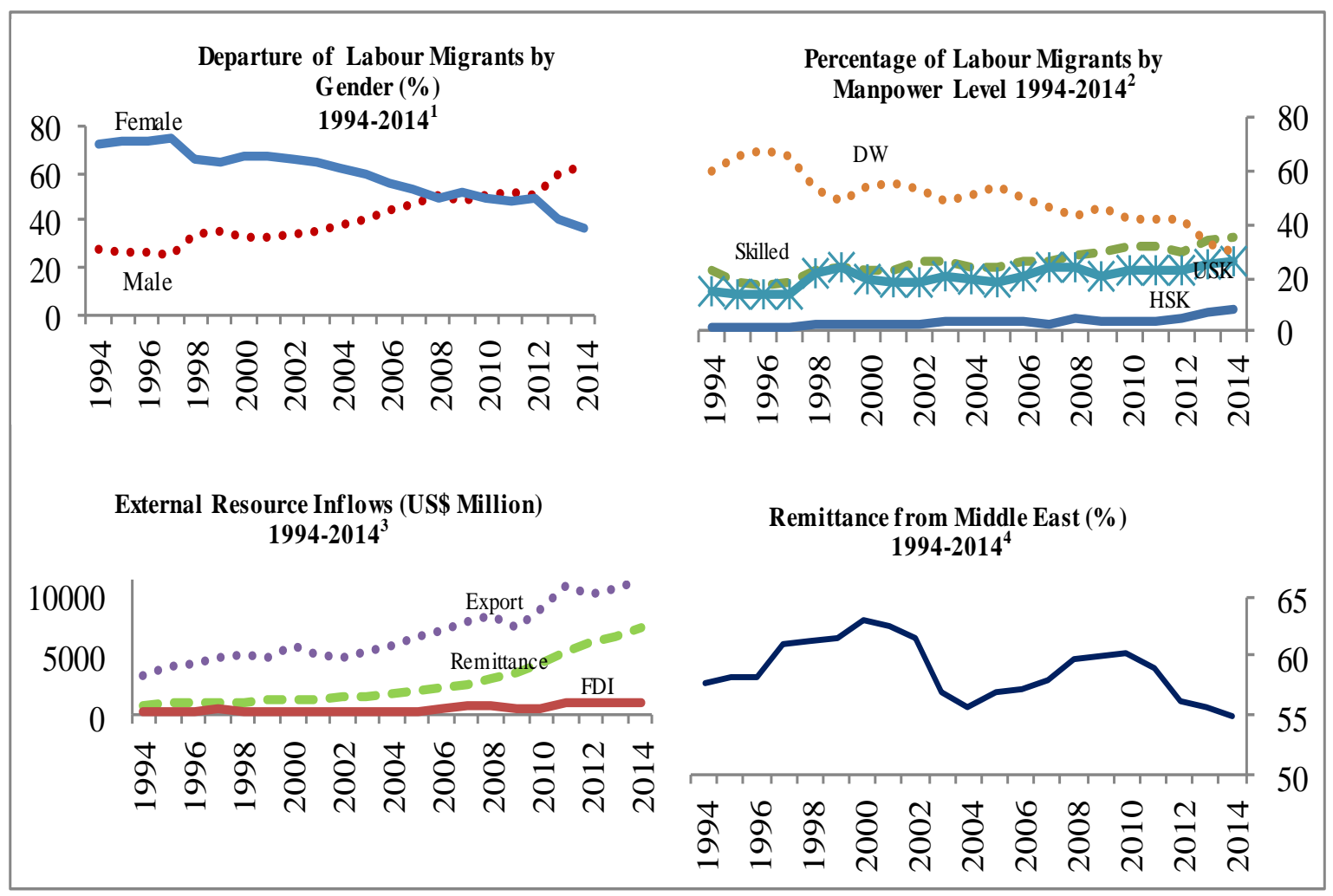

Source: ${ }^{1}$ and ${ }^{2}-$ SLBFE annual statistical reports various issues, ${ }^{3}$ and ${ }^{4}-$ Central Bank annual reports various issues

Notes: ${ }^{2}$ Manpower levels are according to SLBFE classification, HSK-High Skilled workers (professional and middle level migrants), USK-Unskilled Workers. DW-Female Domestic Workers;

${ }^{3}$ FDI- Foreign Direct Investments 



\section{Data, Variables and Methodology}

This study uses data collected from a field survey of labour migration and remittances, conducted by the author from January to March 2014, with the supervision of expertise in social science research and the support of qualified research assistants. Sample of the survey comprised 751 randomly selected households, with and without labour migrants, in Kalutara District, Sri Lanka. Kalutara District is in the western province of the country which has a significantly higher number of labour migrants and an average socioeconomic condition. District consists with urban, rural and estate sectors and hence, cluster sampling method was employed in sample selection. Households were randomly assigned from each cluster considering the representation of households in each sector at the national level. Structured questionnaire, used to collect data, consisted with questions related to demographic and socioeconomic characteristics of the labour migrants and household members, remittance receiving practices and remittance utilization etc.

Study employs the propensity score matching method to examine the objectives. Since some of the households with labour migrants do not receive remittances, comparisons are done between remittance receiving and non-receiving households. Analyses begin with the presentation of descriptive statistics. Then the monthly household income earned from regular and irregular sources are estimated. Standard of living is measured by the proportion of total monthly household income from cost of living index of the country. Income profiles of remittance receiving and nonreceiving households are compared to find the significance of remittances in the income profile of the households. Propensity score matching results are presented in the last part of the analyses. It shows the effects of remittances on household income and standard of living by comparing the average treatment effects.

\section{Descriptive Statistics}

The survey data includes data related to socio-economic characteristics of 751 remittance receiving and non-receiving households. Table 1 presents descriptive statistics of selected variables. 
According to the descriptive statistics, mean age of the household heads is 46 years. A large majority of them have completed their secondary level of education. Size of the households is about three members and most of them have children below 15 years. These households earn over LKR 16,000 monthly income per capita and their standard of living is about 1.08. However, these demographic and socio-economic characteristics are rather different between remittance receiving and non-receiving households.

Table 1: Descriptive Statistics of Selected Variables

\begin{tabular}{|c|c|c|c|c|c|c|}
\hline \multirow{2}{*}{$\begin{array}{l}\text { Variable } \\
\text { Household Characteristics }\end{array}$} & \multicolumn{2}{|c|}{$\begin{array}{c}\text { Remittance } \\
\text { Receiving } \\
\text { Households }\end{array}$} & \multicolumn{2}{|c|}{$\begin{array}{c}\text { Non-Remittance } \\
\text { Receiving } \\
\text { Households }\end{array}$} & \multicolumn{2}{|c|}{ All Households } \\
\hline & Mean & Std. Dev. & Mean & $\begin{array}{l}\text { Std. } \\
\text { Dev. }\end{array}$ & Mean & Std. Dev. \\
\hline Age of the Head & 44.00 & 14.64 & 51.22 & 14.56 & 45.79 & 14.94 \\
\hline \multicolumn{7}{|l|}{ Education Level of Head (\%) } \\
\hline Primary & 10.8 & & 10.2 & & 10.7 & \\
\hline Secondary & 62.6 & & 63.1 & & 62.7 & \\
\hline Post-secondary or higher & 26.2 & & 26.7 & & 26.6 & \\
\hline Household Size & 3.33 & 1.26 & 3.63 & 1.26 & 3.40 & 1.27 \\
\hline Number of children below 5 years & 0.27 & 0.53 & 0.18 & 0.45 & 0.25 & 0.51 \\
\hline Number of children between 5-15 years & 0.60 & 0.80 & 0.43 & 0.67 & 0.56 & 0.77 \\
\hline Number of Adults in household & 3.25 & 1.05 & 3.15 & 1.11 & 3.23 & 1.07 \\
\hline Asset holding & 4.12 & 1.48 & 4.14 & 1.70 & 4.13 & 1.48 \\
\hline Household Income per capita (LKR) & 17755 & 16908 & 13677 & 18580 & 16740 & 17417 \\
\hline Standard of Living & 1.13 & 1.09 & 0.97 & 0.96 & 1.08 & 0.99 \\
\hline $\mathrm{N}$ & \multicolumn{2}{|c|}{564} & \multicolumn{2}{|c|}{187} & & \\
\hline
\end{tabular}

Source: Survey Data

\section{Propensity Score Matching Method}

Researchers use different methods to estimate the effect of a treatment on an outcome. Among them, experiments are done by using randomly selected treatment and control samples or regression analysis. Even though the regression results estimate the cause-effect relationship using observational data, it does not provide any information about the comparability of the cases in the treatment and control samples in terms of distribution $(\mathrm{Li}$, 2012). On the other hand endogeneity can occur due to non-random assignment of the sampling units. Even though the households are randomly 
assigned for treatment and control groups, remittance receiving status can be considered as a latent selection variable. It is determined by many factors that determines the labour migration and remittances. In order to control the selection bias, a logit or probit model can be estimated for the determination of the treatment variable. Then the predicted probabilities of the estimated model can be used in the estimation of the treatment on the outcome $(\mathrm{Li}$, 2012).

Propensity score method provides the support to estimate the counterfactuals using the observational data. It was first developed by Rosenbaum and Rubin in 1983 based on the counterfactual framework. In early studies this method was applied for medical science experimental studies. Applications of propensity score matching method can be found in social science research in 1990s.

It solves the problems of heterogeneity and self-selection in migration studies, in which remittance receiving status of the households is determined by some household characteristics (Bouoiyour \& Miftah, 2015). Propensity scores show the probability of selecting to the treatment group based on the covariates. As shown in Rosenbaum and Rubin (1984) it is necessary to include the covariates related to both treatment and outcome variables. Hence, demographic and socio-economic characteristics that determines migration and remittances were selected as covariates. Matching is done by using different matching methods. Commonly used method is the nearest neighbor matching, which compares the treatment cases with the control cases that have similar or closer propensity scores. If the sample sizes of treatment and control groups are significantly different, matching can be done with replacements (Thommes, 2012).

\section{Stratified Matching Method}

Stratified matching is one of the matching methods used in the propensity score matching analysis, to match the cases of treatment and control samples. In the stratified matching method, cases are sub classified based on the propensity scores. Such sub classification will balance covariate if the units in each subclass are homogeneous and the propensity scores are distributed in similar distribution (Rosenbaum \& Rubin, 1984). Stratified matching is best suited when the sampling units are rather heterogeneous. 
Like in many developing countries, income inequality in Sri Lanka is rather high. Since main variable of interest is household income, stratified matching method is selected in the propensity score analysis of this study.

Following Rosenbaum and Rubin (1985), this study uses five strata to classify the cases into blocks. Hence, 20 percent quintiles of the propensity score are used to categorise the households into five strata. Considering the relative sizes of the control and treatment groups, stratified matching was done with three replacements. Strata balance is tested by using the t-tests run for all the covariates before and after matching. Analysis is done using SPSS 21. Following the empirical literature, cases with less than 0.10 propensity scores are separated as unmatched. After matching with the three replacement ratio the size of the treatment sample reduced to 564 and the controlled sample increased to 184 .

Effect of remittance receiving status on the outcome variables are estimated by the average treatment effect. Causal effect is estimated using the Average Treatment of Treated (ATT). Matched sample is used to estimate the ATT. Average treatment effect (ATT) can be defined as the average difference in the outcome of the remittance receiving and nonreceiving households. Hence the ATT is: ATT $=\mathrm{E}\left(\mathrm{Y}_{1 \mathrm{i}} / \mathrm{R}_{\mathrm{i}=1}\right)-\mathrm{E}\left(\mathrm{Y}_{0 \mathrm{i}} / \mathrm{R}_{\mathrm{i}=0}\right)$.

It is estimated as the average difference in the outcome of the treated group and the matched control groups. It is estimated by the mean difference weighted by the proportion of cases in each stratum.

$$
A T T=\left(\sum_{q=1}^{Q-} \frac{\sum_{i=1} Y_{j}^{R}}{N_{q}^{R}}-\frac{\sum_{j} Y_{j}^{N R}}{N_{q}^{N R}}\right) * \frac{N_{q}^{R}}{N^{R}}
$$

Where, $\mathrm{Y}$ is the outcome, $\mathrm{R}$ is the remittance receiving households, NR is the non-remittance receiving Households, $\mathrm{N}$ sample sizes, $\mathrm{Q}$ is the number of stratum and ATT is the average treatment effect of treated. Weighted sum of ATT is the summation of the weighted ATT. It represents the difference between the outcome of the remittance receiving households and that of their non-remittance receiving counterparts. Since it was revealed that the volume of remittances sent by the labour migrant differ with their skill level, stratified matching is carried out for the households 
with labour migrants in different skill levels. In the sample of the nonremittance receivers, skill level of the main income earner is considered.

\section{Empirical Results}

\section{Volume of Remittance Receipts}

Remittances are one of the income sources of the households with labour migrants. It was found that 89.3 percent of the households with the labour migrants receive the remittances at least once in three months, from their family members working abroad. This implies the implicit contractual arrangement between migrants and households, in which the migrants remit money for the benefit of the household.

\section{Table 2: Volume of Remittances by Selected Demographic and Social Factors}

\begin{tabular}{lccc}
\hline \hline & Amount (LKR) & $\begin{array}{c}\text { \% of Salary remitted } \\
\text { by the migrant }\end{array}$ & \% of Income \\
\hline $\begin{array}{l}\text { Monthly } \\
\text { Receipts } \\
\text { Sector }\end{array}$ & 31577 & 50.93 & 66.29 \\
$\quad$ Urban & 31577 & & \\
Rural & 30551 & 56.64 & 69.87 \\
Estate & 21561 & 53.95 & 66.28 \\
Gender of the Remittance Receiver & 26278 & 47.96 & 62.89 \\
$\quad$ Male & 32506 & 54.03 & 67.05 \\
Female & & 51.21 & 59.71 \\
Gender of Labour Migrant & 25105 & & 56.48 \\
$\quad$ Male & 33795 & 51.96 & 73.16 \\
Female & & 54.97 & \\
Marital Status of the Migrant & & & \\
Single & 35445 & 51.36 & 55.38 \\
Married & 21064 & 57.85 & \\
N = 564 & & & \\
\hline \hline
\end{tabular}

Source: Survey Data

Table 2 presents the volume of remittances received by the households per month. As shown in the table, households receive more than LKR 31,000 per month. However, it is noteworthy that the volume of remittances 
varies with the demographic and socio-economic characteristics of the labour migrants and their households.

Average monthly remittance receipt is high in the urban sector and slightly lower in the rural sector. It is considerably lower in the estate sector compared to urban and rural sectors. However, contribution of the remittances to the household income is rather similar in all of these sectors. Further, female remittance recipients receive larger amounts of remittances compared to males. On the other hand, male labour migrants, remit larger volumes of remittances that contribute more than 70 of the household income. Results show that the married migrants send more remittances compared to the unmarried migrants. Amount remitted, percentage of salary remitted as well as the contribution of remittances to the household income is comparatively higher among the married people than the singles. This shows the effect of family ties between the migrant and household on the probability to remit money shown by Funkhouser (1995).

Table 3: Distribution of Remittance Receipts among Households

\begin{tabular}{lc}
\hline \hline $\begin{array}{l}\text { Volume of Remittance per month } \\
\text { (LKR) }\end{array}$ & \% of Households \\
\hline \hline$<10,000$ & 27.34 \\
$10000-20000$ & 19.24 \\
$20000-30000$ & 17.49 \\
$30000-40000$ & 13.35 \\
$40000-50000$ & 8.43 \\
$50000-60000$ & 4.77 \\
$60000-70000$ & 1.43 \\
$70000-80000$ & 0.95 \\
$80000-90000$ & 2.07 \\
$90000<$ & 4.93 \\
\hline \hline
\end{tabular}

Source: Survey Data

Monthly remittance receipts among the remittance receivers show a significant disparity. As shown in the Table 3, about 30 percent of remittance receiving households receives less than LKR 10,000 per month. 
Their average per capita remittance receipt is about LKR 3,000 per month. This shows that, in a situation when the remittance is the only income source of these households, then they stay below the international poverty line. Contrasting to this, about 5 percent of remittance receiving households receives more than LKR 90,000 per month. This is over LKR 27,000 of per capita remittance receipt. These show a significant disparity in the volume of remittances received by the households that is resulted in high income disparity among the remittance receiving households. This confirms the findings of, Karunarathne (2008), which shows income inequality resulted from labour migration in the Sri Lankan context.

\section{Income portfolio of remittance receiving and non-receiving households}

Inter comparison of remittance receiving and non-receiving households were carried out to find the significance of remittances in the household income profile. Income of the household comprises with income from various sources. These include both regular as well as irregular income sources. Regular sources include salary and wages, business income and other regular income. Irregular income includes income from various properties, agricultural income, bonus/allowances or any other irregular income earned by households. Table 4 compares the income portfolio between remittance receiving and non-receiving households.

It shows significant differences in the level of household income and the number of income sources between remittance receiving and non-receiving households. As shown in the table, both groups of households earn income from different regular and irregular income sources. Remittance is the most significant source of the income among the remittance receiving households. It is more than twice of their regular income.

Compared to the non-remittance receiving households, remittance receiving households enjoy a higher level of income. Remittance receiving households enjoy more than LKR 6000 per month on average compared to their non-remittance receiving counterparts. Empirical studies of Munas, (2008); De and Ratha, (2012) and Samaratunge et al. (2012), also show that remittances raise the financial condition of the households in the Sri Lankan context. As shown in the theory of NELM, as part of the implicit contractual arrangement, households with labour migrants receive remittances that 
enhance their income level. Similar results have found in empirical studies of Koc and Onan (2004); Sosa and Medina (2006); Kibikyo and Ismail (2012); Waheed and Adebayo (2012) and Adams and Page (2005), carried out in other labour sending developing countries.

Further, it is interesting to note in the results that, number of income sources of the remittance receiving households is significantly higher than their non-remittance receiving counterparts. While more than half of the non-remittance receiving households receive income from only one source, over two third of the remittance receiving households enjoy income from two or more sources. This confirms the income diversification of the households of labour migrants, discussed in the theory of NELM. Labour migrants remit money as a diversification strategy to reduce the risk face by the households (Stark \& Levhari, 1982; Stark, 1991). Hence, they enjoy income from multiple sources that compared to other households.

\section{Results of the Propensity Score Matching Analysis}

Objective of the propensity score matching analyses is to examine the effect of the remittances on the income and the standard of living of the remittance receiving households. First, a logistic model is used to estimate the propensity scores. Second, Average Treatment Effects (ATT) related to income and standard of living is estimated using the stratified matching method in propensity score analysis. 
Remittances from International Labour Migrants and the Standard of Living of the Left Behind Households in Sri Lanka

Table 4: Household Income Portfolio (LKR)

\begin{tabular}{|c|c|c|c|c|c|c|}
\hline \multirow[t]{2}{*}{ Income Source } & \multicolumn{2}{|c|}{$\begin{array}{l}\text { Remittance } \\
\text { Receivers }\end{array}$} & \multicolumn{2}{|c|}{$\begin{array}{l}\text { Non-Remittance } \\
\text { Receivers }\end{array}$} & \multicolumn{2}{|c|}{ Pooled Sample } \\
\hline & Mean & $\begin{array}{c}\% \text { of } \\
\text { Income }\end{array}$ & Mean & $\begin{array}{c}\% \text { of } \\
\text { Income }\end{array}$ & Mean & $\begin{array}{l}\% \text { of } \\
\text { Income }\end{array}$ \\
\hline $\begin{array}{l}\text { Total Regular } \\
\text { Income }\end{array}$ & 16793 & 28.25 & 39876 & 75.85 & 22540 & 40.01 \\
\hline Salary/wage & 14130 & 24.02 & 33631 & 63.31 & 18085 & 33.78 \\
\hline Business Income & 1663 & 2.52 & 19283 & 12.81 & 6050 & 5.072 \\
\hline Other Regular & 1000 & 1.76 & 1400 & 4.16 & 1099 & 2.35 \\
\hline $\begin{array}{l}\text { Total Irregular } \\
\text { Income }\end{array}$ & 1909 & 5.44 & 3684 & 22.22 & 2351 & 9.58 \\
\hline Property Income & 529 & 0.46 & 2374 & 2.28 & 989 & 0.91 \\
\hline $\begin{array}{l}\text { Agriculture } \\
\text { Income }\end{array}$ & 4166 & 3.91 & 4786 & 9.93 & 4320 & 5.40 \\
\hline Bonus etc. & 768 & 0.60 & 997 & 0.82 & 825 & 0.66 \\
\hline $\begin{array}{l}\text { Other Irregular } \\
\text { Income }\end{array}$ & 203 & 0.27 & 960 & 1.16 & 391 & 0.49 \\
\hline Remittances & 31577 & 66.29 & - & - & 25192 & 50.33 \\
\hline $\begin{array}{l}\text { Household Income } \\
\text { (without } \\
\text { Remittances) }\end{array}$ & 18703 & & 43560 & & 24892 & \\
\hline $\begin{array}{l}\text { Household Income } \\
\text { (with Remittances) }\end{array}$ & 50280 & & 43560 & & 50085 & \\
\hline $\mathrm{N}$ & 564 & & 187 & & 751 & \\
\hline \multicolumn{7}{|c|}{ Number of Income Sources ( \% of Households) } \\
\hline 1 & 33.2 & & 54.1 & & 37.0 & \\
\hline 2 & 50.1 & & 36.9 & & 48.1 & \\
\hline 3 & 13.8 & & 8.2 & & 12.9 & \\
\hline 4 or more & 2.9 & & 0.8 & & 1.9 & \\
\hline
\end{tabular}

Source: Survey Data 
Table 5: Estimated ATT on Income and Standard of Living: Stratified Matching Results

\begin{tabular}{|c|c|c|c|c|c|c|c|}
\hline \multirow[t]{2}{*}{ Strata } & \multirow[t]{2}{*}{ Sample } & \multirow[t]{2}{*}{$\mathrm{N}$} & \multirow[t]{2}{*}{ Weight } & \multicolumn{2}{|c|}{ Effect on Income (LKR) } & \multicolumn{2}{|c|}{ Effect on Standard of Living } \\
\hline & & & & $\begin{array}{c}\text { Estimated } \\
\text { ATT }\end{array}$ & $\begin{array}{c}\text { ATT } \\
\text { difference } \\
\text { (weighted) }\end{array}$ & $\begin{array}{c}\text { Estimated } \\
\text { ATT }\end{array}$ & $\begin{array}{c}\text { ATT } \\
\text { difference } \\
\text { (weighted) }\end{array}$ \\
\hline \multirow[t]{2}{*}{1} & $\mathrm{RR}$ & 41 & 0.07 & 17396.36 & \multirow{2}{*}{289.79} & 1.23 & \multirow[t]{2}{*}{0.012} \\
\hline & NR & 94 & & 13205.56 & & 1.05 & \\
\hline \multirow[t]{2}{*}{2} & $\mathrm{RR}$ & 110 & 0.22 & 18638.00 & \multirow{2}{*}{629.05} & 1.14 & \multirow[t]{2}{*}{0.035} \\
\hline & NR & 41 & & 15729.95 & & 0.98 & \\
\hline \multirow[t]{2}{*}{3} & $\mathrm{RR}$ & 127 & 0.23 & 19164.82 & \multirow[t]{2}{*}{2258.55} & 1.21 & \multirow[t]{2}{*}{0.141} \\
\hline & NR & 23 & & 9213.10 & & 0.59 & \\
\hline \multirow[t]{2}{*}{4} & $\mathrm{RR}$ & 139 & 0.26 & 17522.12 & \multirow{2}{*}{699.14} & 1.12 & \multirow[t]{2}{*}{0.008} \\
\hline & NR & 10 & & 14783.84 & & 1.09 & \\
\hline \multirow[t]{2}{*}{5} & $\mathrm{RR}$ & 145 & 0.23 & 15994.91 & \multirow[t]{2}{*}{278.21} & 1.01 & \multirow[t]{4}{*}{0.102} \\
\hline & NR & 6 & & 14769.05 & & 0.56 & \\
\hline \multirow[t]{2}{*}{$\mathrm{N}$} & $\mathrm{RR}$ & 564 & & & & & \\
\hline & NR & 187 & & & & & \\
\hline \multicolumn{4}{|c|}{ Weighted Sum of ATT } & & \multicolumn{2}{|l|}{$4148.79 * *$} & $0.298 * *$ \\
\hline \multicolumn{5}{|c|}{ Improvement (ATT difference as a \% of ATT of NR ) } & 30.83 & & 36.12 \\
\hline
\end{tabular}

Source: Survey Data

Note: RR-Remittance Receiving Households, NR-Non-remittance Receiving Households; ATT Average Treatment Effect, **<0.05 confidence level

Main two types ATT are estimated, related to household income and standard of living. First, ATT are estimated for the effect of remittances on household income and standard of living. Second, ATT related to household income is estimated for the households in each income quintiles. These show the improvement of the household income and standard of living through remittances.

Results of the strata balance confirmed that after matching, values of most of the covariates between remittance receiving and non-receiving samples are not significantly different in each stratum. This confirms that after matching samples are suitable for the comparison. Average Treatment 
Effects of remittances on the household income per capita and the standard of living are presented in Table 5.

With reference to the household income per capita, positive ATT differences in all matched strata show that, remittance receiving households enjoy higher income per capita compared to their non-remittance receiving counterparts. Total effect of the remittances on the household income is found as LKR 4,148. It is about 31 percent increase in the household income per capita, when the income difference is calculated as a percentage of relevant ATT of the non-remittance receiving households.

With reference to the standard of living index, positive values in each stratum present enhancement of the standard of living of the remittance receiving households compared to their non-remittance receiving counterparts. Improvement of the standard of living index is about 36 percent, when the difference is calculated as a percentage of relevant ATT of the non-remittance receiving households.

These results show that remittances have improved the household income and the standard of living of the remittance receiving households in a considerable percentage. Results provide evidence for the altruistic behavior of labour migrants shown in the theory of NELM that motivate them to remit money to enhance financial status of their households left behind. Since migration is considered as a collective decision and the migrants and the households have implicit contractual arrangements, households with labour migrants get the opportunity to enjoy higher income through the remittances they receive from their family members working abroad. Similar results have found in studies carried out by; Adams (1991); Cuong (2008); Kock and Onan (2004) and Castaldo and Reilly (2007) in various developing country settings using different methodological approaches.

Improvement of the household income is then estimated for the households in each income quintile to find, whether the improvement of the household income through remittances is common for the households in each income level. Income quintiles are based on the non-remittance income, estimated by the self-assessments of the households, about their 
total household income in the absence of labour migration and remittance receipts.

Figure 2: Improvement of Income per capita by Income Quintile

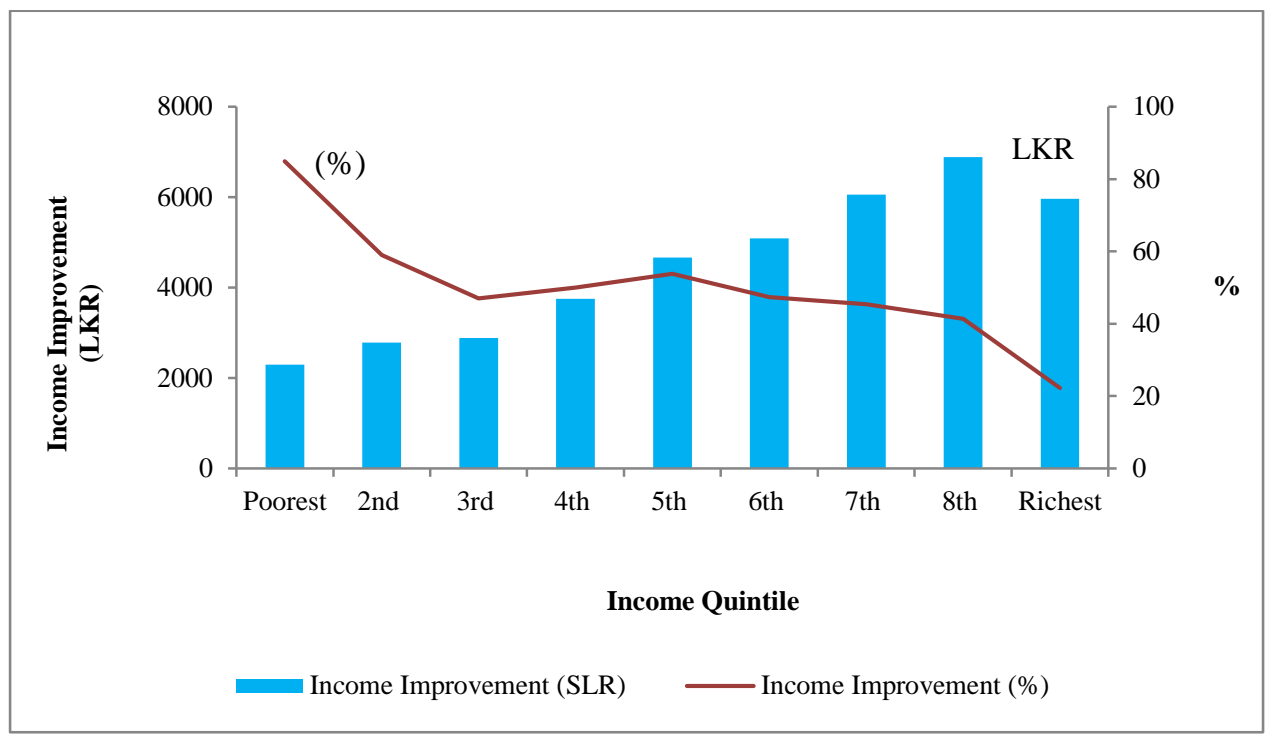

Source: Survey Data

Note: Income quintile is based on the self estimated non-remittance income

Average treatment effect of the income improvement is estimated for the households in each income quintile. Figure 2 presents the estimated difference in the ATT between remittance receiving and non-receiving households and the income improvement as a percentage of the ATT of non-remittance receiving households. Results show that, remittances have improved the income per capita of the households in each income quintile. Amount of the income improvement is higher among the households in high income quintiles. However, it is interesting to note that, percentage improvement of the household income is higher among the households in low income quintiles. It is about 85 percent increase among the poorest and about 22 percent among the richest. This implies that, even though the effect of remittances on household income is small in size among the poorest households, it is a significant improvement compared to the income earned by the non-remittance receiving households in the same income quintile. 


\section{Conclusion}

This paper intended to elucidate the significance of remittances in the income profile of the households and examine the impact of remittance on income and standard of living of the remittance receiving households in Sri Lanka. Survey data were analyzed using thematic analyses and propensity score matching method. It was found that about 89 percent of the households with labour migrants receive remittances. Volume remitted by the labour migrant varies with the demographic and socio-economic characteristics of the migrant and the household. Hence, there is a significant disparity in the amount remitted and the contribution of remittances to the household income of the remittance receiving households. Both remittance receivers and non-receivers receive income from different regular and irregular sources. Remittance is the largest component in the income profile of the remittance receiving households. It is not totally an additional income to the household. Part of it covers the foregone labour income due to migration. However, remittance receiving households enjoy a significantly large income compared to their non-remittance receiving counterparts. Further, remittance receiving households receive income from number of sources that confirms the income diversification of the remittance receivers shown in the literature. Results of the stratified matching analysis show a significant effect of remittances on household income and standard of living of the remittance receiving households. It was found that, remittances have improved the income and the standard of living 30 to 36 percent. Results of the study compatible with the studies carried out by Adams (1991); Adams and Page (2005); Arunatilake, et al. (2010); Chen, et al. (2003); Cuong (2008) in various country contexts. Improvement of the household income is higher among the households in high non-remittance income quintile. However, percentage change in the income is higher among the low income earning households.

\section{References}

Adams, R. (1991). The economic uses and impact of international remittances in rural Egypt. Economic Development and Cultural Change, 39(4), 695-722.

Adams, R. (2005). Remittances, household expenditure and investment in Guatemala. World Bank Policy Research Working Paper (3532). World Bank, Washington DC. 
Adams, R., \& Page, J. (2005). Do international migration and remittances reduce poverty in developing countries? World Development, 33(10), $1645-1669$.

Agrawal, R., \& Horowitz, A. (2002). Are internatinal remittance altruism or insurance? Evidecne from Guyana using multiple-migrant households. World Development, 30, 2033-2044.

Ariola, J. (2008). Labour supply in response to remittance income: The case of Mexico. The Journal of Developing Areas, 41 (2), 69-77.

Arunatilake, N., Jayaratne, S., Jayawardene, P., Jayaweera, R., \& Weerakoon, D. (2010). Impact of remittances on the household of the emigrant and on the economy of the migrant's country: Sri Lanka.Institute of Policy Studies of Sri Lanka.

Bouoiyour, J., \& Miftah, A. (2015). The impact of migrant workers' remittances on the living standards of families in Morocco: A Propensity Score Matching Approach. Migration Letters. 12 (1), 1327.

Brown, R. P., \& Leeves, G. (2007). Impacts of international migration and remittances on source country household incomes in small island States: Fiji and Tonga. School of Economics, University of Queensland.

Bussolo, M., \& Medvedev, D. (2007). Do remittance have a flip side? A general equilibrium analysis of remittances, labour supply responses and policy options for Jamaica.World Bank.

Castaldo, A., \& Reilly, B. (2007). Do migrant remittances affect the consumption pattern of Albanian households? South-Eastern Europe Journal of Economics, 1, 25-54.

Central Bank. (2013). Economic and social statistics of Sri Lanka. Colombo: Central Bank of Sri Lanka.

Central Bank. (2015). Economic and social statistics. Colombo: Central Bank of Sri Lanka.

Chen, K..P., Chiang, S.H., \& Leung, S.F. (2003). Migration, family and risk diversification. Journal of Labour Economics, 21 (2), 323-352.

Clemens, M., Montenegro, C., \& Pritchett, L. (2008). The place premium: Wage differences for identical workers across the US border. Washington DC: World Bank.

Cuong, N. V. (2008). Impacts of international and internal remittances on household welfare: Evidence from Vietnam. Asia Pacific Development Journal, 16(1), 59-92.

De, P. K., \& Ratha, D. (2012). Impact of remittances on household income, asset and human capital: Evidence from Sri Lanka. Migration and Development, 1(1), 163-179. 
Funkhouser, E. (1995). Remittances from international migration: A comparison of El Salvador and Nicaragua. The Review of Economics and Statistics 77, 137-146.

Karunarathne, H.D. ( 2008). International labour migration, remittances and income inequality in a developing country: The case of Sri Lanka. Hosei Economic Review 75(3), 21-65.

Kibikyo, D., \& Ismail,O. (2012). Remittances effects on poverty and social development in Mogadishu, Somalia. Microeconomics and Macroeconomics, 1(1).

Koc, I., \& Onan, I. (2004). International migrant's remittances and welfare status of the left-behind families in Turkey. International Migration Review, 38(1), 78-112.

Li, M. (2012). Using the propensity score method to estimate causal effects: A review and practical guide. Organizational Research Methods, 39 (1).

Munas, M. (2008). Moving out of poverty: The role of remittances. Colombo: Center for Poverty Analysis (CEPA).

Rosenbaum, P., \& Rubin, D. (1983). The central role of propensity score in observational studies for causal effects. Biometrica, 70, 41-55.

Rosenbaum, P. R., Rubin, D. B. (1984). Reducing bias in observational studies using sub-classification on the propensity score. Journal of the American Statistical Association, 79 (387), 516-524.

Samaratunge, P., Jayaweera, R., \& Perera, N. (2012). Impact of migration and remittances on investment in agriculture and food security in Sri Lanka.Research Studies: Agricultural Economic Policy Series. Institute of Policy Studies of Sri Lanka.

SLBFE. (2010), (2012), (2013). Annual Statistical Report. Battaramulla: Sri Lanka Bureau of Foreign Employment.

Sosa, C., \& Medina, C. (2006). Migration as a safety net and effects of remittances on household consumption: The case of Colombia, Borradore de Economia 41(4).

Stark, O. (1991). Migration in LDCs: Risk, remittances and family. Finance and Development 28(4), 39-41.

Stark, O., \& Bloom, D. (1985). The new economics of labour migration. The American Economic Review, 75 (2), 173-178.

Stark, O., \& Levhari, D. (1982). On Migration and risk in LDCs. Economic Development and Cultural Change, 31, 191-196.

Stark, O., \& Lucas, R. E. (1988). Migration, remittances and the family. Development and Cultural Change, 36(3), 465-481.

Taylor, E., Joaquin, A., Hugo, G., Kouaouci, A., Massey, D., \& Pellegrino, A. (1996). International migration and community development. Population Index, 62(3), 397-418. 
Thommes, F. (2012).Propensity score matching in SPSS retrieved. Retrieved 20th June 2015, from http://www.human.cornell.edu/hd/qml/upload/Thoemmes_2012.pdf

UN (United Nations). (2013). International Migration Report. New York: United Nations.

UN, (1976). Population of Sri Lanka, Country monograph series. Bankok: ESCAP.

Waheed, O., \& Adebayo, S. (2012). Remittances and income inequality in rural Nigeria. Business Management and Economics, 3(5), 210-221.

Wouterse, F., \& Taylor, E. (2007). Migration and income diversification: Evidence from Burkina Faso. World Development, 36(4), 625-640. 